University of Nebraska - Lincoln

DigitalCommons@University of Nebraska - Lincoln

2006

\title{
Wet Corn Gluten Feed and Alfalfa Hay Levels in Dry-Rolled Corn Finishing Diets: Effects on Finishing Performance and Feedlot Nitrogen Mass Balance
}

\author{
T. B. Farran \\ University of Nebraska-Lincoln \\ Galen E. Erickson \\ University of Nebraska-Lincoln, gerickson4@unl.edu \\ Terry Klopfenstein \\ University of Nebraska-Lincoln, tklopfenstein1@unl.edu \\ C. N. Macken \\ University of Nebraska-Lincoln \\ R. Lindquist \\ University of Nebraska-Lincoln
}

Follow this and additional works at: https://digitalcommons.unl.edu/animalscifacpub

Part of the Animal Sciences Commons

Farran, T. B.; Erickson, Galen E.; Klopfenstein, Terry; Macken, C. N.; and Lindquist, R., "Wet Corn Gluten Feed and Alfalfa Hay Levels in Dry-Rolled Corn Finishing Diets: Effects on Finishing Performance and Feedlot Nitrogen Mass Balance" (2006). Faculty Papers and Publications in Animal Science. 464. https://digitalcommons.unl.edu/animalscifacpub/464

This Article is brought to you for free and open access by the Animal Science Department at DigitalCommons@University of Nebraska - Lincoln. It has been accepted for inclusion in Faculty Papers and Publications in Animal Science by an authorized administrator of DigitalCommons@University of Nebraska - Lincoln. 


\title{
Wet corn gluten feed and alfalfa hay levels in dry-rolled corn finishing diets: Effects on finishing performance and feedlot nitrogen mass balance ${ }^{1}$
}

\author{
T. B. Farran, * G. E. Erickson, ${ }^{2}$ T. J. Klopfenstein, ${ }^{*}$ C. N. Macken, ${ }^{*}$ and R. U. Lindquist $\dagger^{3}$ \\ *Department of Animal Science, University of Nebraska, Lincoln 68583-0908; \\ $\dagger$ Archer Daniels Midland Company, Columbus, NE
}

\begin{abstract}
One-hundred ninety-two crossbred steers (initial BW $=351 \pm 11 \mathrm{~kg}$ ) were used to determine the effects of removing alfalfa hay $(\mathrm{AH})$ from dry-rolled corn-based diets containing wet corn gluten feed (WCGF) on animal performance and nutrient ( $\mathrm{N}$ and $\mathrm{OM}$ ) mass balance in open feedlot pens. Steers were stratified by weight and assigned randomly to 24 pens $(2 \times 3$ factorial $)$ and fed for $132 \mathrm{~d}$ from June to October 2002. Experimental diets contained either 0 or $35 \%$ WCGF and $0,3.75$, or $7.5 \% \mathrm{AH}$, and were formulated to be isonitrogenous. For efficiency of gain, an interaction occurred $(P=0.09)$ between AH and WCGF. Feed efficiencies of cattle fed $35 \%$ WCGF were improved $4.4 \%$ $(P=0.10)$ compared with efficiencies of cattle fed no WCGF at $0 \% \mathrm{AH}$; there was a marked improvement in ADG for cattle fed WCGF compared with no WCGF in diets with $0 \% \mathrm{AH}$. Within 35\% WCGF diets, efficiency decreased as $\mathrm{AH}$ inclusion increased $(P=0.06)$. Efficiency was equal across AH levels when 0\% WCGF was fed; however, $\mathrm{ADG}$ was decreased when $\mathrm{AH}$ was removed. Interactions between AH and WCGF were not detected for other performance or carcass criteria; therefore, main effects of AH and WCGF are discussed.
\end{abstract}

Daily intake, ADG, and HCW increased linearly $(P<$ 0.05 ) as dietary AH level increased. Feeding 35\% WCGF also resulted in greater DMI $(P<0.01)$ and a tendency for greater ADG and HCW $(P \leq 0.10)$ compared with steers fed no WCGF. Interactions between $\mathrm{AH}$ and WCGF were not observed for feedlot $\mathrm{N}$ mass balance. As level of $\mathrm{AH}$ increased across diets, $\mathrm{N}$ intake, $\mathrm{N}$ retention, and $\mathrm{N}$ excretion increased $(P<0.05)$. Steers fed $35 \%$ WCGF consumed and excreted more N $(P<0.01)$ than those fed no WCGF. More manure DM $(P=0.11)$, $\mathrm{OM}$, and $\mathrm{N}(P<0.01)$ were removed from pens housing steers fed 35\% WCGF as well as greater OM and N recovery in finished compost. More N (kilogram/steer) was also lost to volatilization as a result of greater $\mathrm{N}$ excretion when WCGF was fed. Expressed as a percentage of $\mathrm{N}$ excretion, loss of $\mathrm{N}$ from pens housing steers fed 0 and 35\% WCGF was not different, averaging nearly $80 \%$. These data suggest that $\mathrm{AH}$ has less value when dry-rolled corn-based diets contain 35\% WCGF and can be decreased from conventional levels. Furthermore, loss of $\mathrm{N}$ from open feedlot pens is high during the summer months, and feeding WCGF may not reduce N losses during these times of year.

Key words: cattle, feedlot, maize gluten, nitrogen, roughage, volatilization

(C2006 American Society of Animal Science. All rights reserved.

J. Anim. Sci. 2006. 84:1205-1214

\section{INTRODUCTION}

Wet corn gluten feed (WCGF) is a high fiber, low starch feed by-product of the corn wet milling industry. Research has shown WCGF can replace up to $50 \%$ of corn in finishing diets (Hussein and Berger, 1995; Richards et al., 1998). Stock et al. (2000) concluded WCGF contained 90 to $114 \%$ the energy value of corn for fin-

\footnotetext{
${ }^{1}$ A contribution of the University of Nebraska Agricultural Division, Lincoln, NE. Journal Series No. 14516. This research was supported in part by funds provided through the Hatch Act.

${ }^{2}$ Corresponding author: geericks@unlnotes.unl.edu

${ }^{3}$ Address: 13542 P Road, Osceola, NE 68651.

Received June 6, 2005.

Accepted December 27, 2005.
}

ishing cattle (dependent upon bran to steep ratio of WCGF). This response is thought to occur as a result of WCGF decreasing rumen starch load and the incidence of ruminal acidosis (Krehbiel et al., 1995). Typically, roughages such as alfalfa hay $(\mathbf{A H})$ are used to control acidosis in finishing diets, and an increase in DMI and ADG is often observed with a small amount (i.e., $\leq 10 \%$ diet $\mathrm{DM}$ ) of roughage inclusion (Stock et al., 1990; Huffman et al., 1992; Shain et al., 1999). Due to a reduced starch load and the positive attributes of feeding WCGF relative to acidosis, conventional levels of roughage may not be necessary when WCGF is incorporated into finishing diets.

Environmental issues surrounding cattle feedlots are continuing to escalate. A predominant concern is $\mathrm{N}$ volatilization from feedlot surfaces. Nitrogen can nega- 
Table 1. Composition of finishing diets (\% DM basis)

\begin{tabular}{|c|c|c|c|c|c|c|}
\hline \multirow[b]{3}{*}{ Item } & \multicolumn{3}{|c|}{$0 \% \mathrm{WCGF}$} & \multicolumn{3}{|c|}{$35 \%$ WCGF } \\
\hline & \multicolumn{3}{|c|}{ AH level, \% } & \multicolumn{3}{|c|}{ AH level, \% } \\
\hline & 0 & 3.75 & 7.5 & 0 & 3.75 & 7.5 \\
\hline Dry-rolled corn & 87.0 & 83.25 & 79.5 & 52.0 & 48.25 & 44.5 \\
\hline Wet corn gluten feed ${ }^{1}$ & - & - & - & 35.0 & 35.0 & 35.0 \\
\hline Alfalfa hay & - & 3.75 & 7.5 & - & 3.75 & 7.5 \\
\hline Molasses & 5.0 & 5.0 & 5.0 & 5.0 & 5.0 & 5.0 \\
\hline Tallow & 3.0 & 3.0 & 3.0 & 3.0 & 3.0 & 3.0 \\
\hline \multicolumn{7}{|l|}{ Supplement ${ }^{2}$} \\
\hline Limestone & 1.66 & 1.53 & 1.40 & 1.59 & 1.46 & 1.32 \\
\hline Fine ground corn & 1.30 & 1.65 & 1.99 & 2.66 & 2.89 & 3.13 \\
\hline Urea & 1.23 & 1.12 & 1.01 & 0.21 & 0.11 & - \\
\hline Salt & 0.30 & 0.30 & 0.30 & 0.30 & 0.30 & 0.30 \\
\hline Tallow & 0.15 & 0.15 & 0.15 & 0.15 & 0.15 & 0.15 \\
\hline $\mathrm{KCl}$ & 0.26 & 0.16 & 0.05 & - & - & - \\
\hline Trace mineral & 0.05 & 0.05 & 0.05 & 0.05 & 0.05 & 0.05 \\
\hline Vitamin A, D, E & 0.01 & 0.01 & 0.01 & 0.01 & 0.01 & 0.01 \\
\hline Rumensin premix & 0.019 & 0.019 & 0.019 & 0.019 & 0.019 & 0.019 \\
\hline Tylan premix & 0.014 & 0.014 & 0.014 & 0.014 & 0.014 & 0.014 \\
\hline \multicolumn{7}{|l|}{ Nutrient composition $^{3}$} \\
\hline $\mathrm{CP}$ & 13.0 & 13.0 & 13.0 & 13.5 & 13.5 & 13.5 \\
\hline $\mathrm{DIP}^{4}$ & 7.21 & 7.29 & 7.36 & 7.57 & 7.65 & 7.74 \\
\hline $\mathrm{Ca}$ & 0.70 & 0.70 & 0.70 & 0.70 & 0.70 & 0.70 \\
\hline $\mathrm{P}$ & 0.38 & 0.38 & 0.38 & 0.49 & 0.49 & 0.48 \\
\hline
\end{tabular}

${ }^{1}$ Wet corn gluten feed from ADM, Columbus, NE.

${ }^{2}$ Provided $34 \mathrm{mg}$ of monensin and $12 \mathrm{mg}$ of tylosin per kilogram of diet DM.

${ }^{3}$ Crude protein and $\mathrm{P}$ were analyzed; other nutrients were calculated.

${ }^{4} \mathrm{DIP}=$ degradable intake protein.

tively affect air and water quality, and methods are needed to reduce $\mathrm{N}$ losses to the environment. Feeding corn bran to increase OM excretion onto the pen surface has reduced $\mathrm{N}$ volatilization during the winter/spring feeding months (Erickson and Klopfenstein, 2001b; Adams et al., 2004). However, decreasing diet digestibility with corn bran may also decrease animal performance. The combination of steep liquor and corn bran in WCGF may allow performance to be maintained and help to reduce $\mathrm{N}$ loss.

The objectives of this research were to determine 1) if WCGF can be effectively utilized as an energy source and reduce the need for conventional levels of roughage in corn-based diets; and 2) if feeding WCGF will increase $\mathrm{OM}$ on the pen surface, thereby increasing manure $\mathrm{N}$ and decreasing $\mathrm{N}$ losses during warm summer feeding months.

\section{MATERIALS AND METHODS}

\section{Feedlot Performance}

Animal procedures were reviewed and approved by the University of Nebraska Institutional Animal Care and Use Committee. To determine the effects of removing $\mathrm{AH}$ from diets with and without WCGF, 192 yearling crossbred steers (initial BW $=351 \pm 11 \mathrm{~kg}$ ) were fed for $132 \mathrm{~d}$ from June to October during the summer of 2002. Steers were weighed initially on 2 consecutive days after being limit-fed ( $2 \%$ of BW) a $50 \%$ AH:50\%
WCGF diet for $5 \mathrm{~d}$ to minimize gut fill differences. Steers were then stratified by BW on $d 0$ and assigned randomly to 24 feedlot pens ( 8 steers/pen) within each weight strata. Steers were sorted on d 1 before placement in pens. Initial BW was the average of both $\mathrm{d} 0$ and 1 . Pens were assigned randomly to 1 of 6 dietary treatments arranged in a $2 \times 3$ factorial design (4 pens per treatment). Final finishing diets contained 0 or $35 \%$ WCGF and 0, 3.75, or 7.5\% AH (Table 1). Experimental diets were formulated to meet or exceed MP requirements (NRC, 1996) and to be isonitrogenous with the $35 \%$ WCGF and 7.5\% AH treatment diet. Urea served as the supplemental protein source to equalize CP among the 6 dietary treatments.

Adaptation to finishing diets consisted of a 23-d stepup period where dry-rolled corn progressively replaced $\mathrm{AH}$. Because of different final AH inclusions, the adaptation diets fed initially differed in alfalfa level, so that the roughage change across steps was identical between treatments. Steps were 37.5, 27.5, 17.5, 7.5, and 0\% $\mathrm{AH}$ fed for 5, 4, 7, and $7 \mathrm{~d}$, respectively, for the $0 \% \mathrm{AH}$ treatments. The steps for the $7.5 \% \mathrm{AH}$ treatments were similar, except the initial amount of $\mathrm{AH}$ was $45 \%$.

Dietary treatments were fed once daily in the morning throughout the finishing period. Steers were implanted on d 1 with Synovex-C (Fort Dodge Animal Health, Overland Park, KS) and reimplanted on d 30 with Revalor-S (Intervet, Inc., Somerville, NJ). Upon completion of the feeding trial, cattle were slaughtered at a commercial abattoir, and carcass data were col- 
lected. Final BW was calculated from HCW using a common dressing percent (63\%), with all carcasses included. Carcass trim was not excessive for any carcasses. After a 24-h chill, 12th-rib fat thickness and LM area were collected along with USDA Yield Grade calculated and marbling score as determined by a USDA grader.

\section{Nutrient Balance}

Mass balance for $\mathrm{N}$ was conducted as previously outlined (Bierman et al., 1999; Erickson and Klopfenstein, 2001a; Adams et al., 2004) in each of the 24 feedlot pens. Stocking density in all pens was maintained at $30.8 \mathrm{~m}^{2}$ per steer. The pens were cleaned before the cattle were placed in them. Throughout the feeding period, feed refusals were collected when necessary (after precipitation events or once per week) to accurately assess DM and nutrient intake. After cattle were removed from the pens, manure was scraped and piled into 1 central pile within each pen. As the manure was being loaded out of pens, manure samples were taken. Manure was weighed on an as-is basis and hauled to the University of Nebraska compost yard. To calculate fecal $\mathrm{N}$ excretion, which allows for fecal $\mathrm{N}$ excretion to be evaluated as a percentage of total $\mathrm{N}$ excretion, fecal samples were collected from the pen surface (fresh feces with no manure or soil contamination) once every $2 \mathrm{wk}$ during the finishing period.

Seven earthen retention ponds collected runoff from 12 of the 24 feedlot pens. Pens assigned to the same treatment drained into the same runoff retention pond, and no more than 2 pens drained into 1 pond. To test for treatment differences, runoff data were only from pens with retention ponds. For runoff, all treatments were equally represented in pens with and without retention ponds. Because runoff is not a large contributor to nutrient losses (Gilbertson et al., 1971; Adams et al., 2004) and only 36\% (Clark et al., 1975) to $48 \%$ (Gilbertson et al., 1971) of precipitation results in runoff, this approach seemed appropriate in estimating nutrient runoff from pens without runoff retention ponds. In the case of a runoff event, effluent was collected in the ponds, then drained within 6 to $18 \mathrm{~h}$ through a PVC pipe, sampled, and the volume quantified using an ISCO model 4230 air-bubble flow meter (ISCO, Lincoln, NE). Analyses were conducted on samples collected during draining.

To account for inherent differences in cleaning from pen to pen, soil in clean pens was sampled before cattle were placed into them and again after cleaning (i.e., after the cattle were marketed). Soil core samples were used to correct for variation in cleaning from pen to pen and manure/soil mixing by cattle activity during the experiment. Pen core samples account for either $\mathrm{N}$ addition or loss from pen soil by determining total pen $\mathrm{N}$ both before and after the experiment. The difference in pen $\mathrm{N}$ before and after the experiment was used as an adjustment for manure $\mathrm{N}$ removal. To account for sampling variation, core locations were evenly spaced throughout each pen on a grid pattern. Sixteen soil cores (15-cm depth, 2.5 -cm diameter soil probe) were obtained from each pen, and each core represented 15.3 $\mathrm{m}^{2}$. Manure nutrient data are presented both with and without the soil core adjustment.

Manure composting was done in windrows during the summer months. One compost windrow was formed for all manure removed from pens assigned to the same experimental treatment (4 pens/compost windrow). Manure compost was turned once before winter (October) at the end of the trial, and then turning resumed the following May when ambient temperatures were warm. Compost was considered finished when windrows no longer produced heat 2 to $7 \mathrm{~d}$ after turning, based on 2 measurements on each of those days. After the composting process was completed, 1 random sample within each $3 \mathrm{~m}$ of windrow was taken on both sides of a compost windrow. Samples were mixed and subsampled to obtain 1 representative sample for each compost windrow. Samples were analyzed for DM, N, and ash concentrations. Organic matter was calculated by the difference between the DM and ash content. Compost $\mathrm{N}$ and $\mathrm{OM}$ recoveries were calculated based on manure quantity for each nutrient removed at pen cleaning. To estimate compost DM loss and adjust compost nutrient recoveries, assuming no loss of ash, ash concentrations before composting (manure) and after composting were used as an internal marker. Ash, N, and OM concentrations were on a DM-basis in the following equation:

$$
\begin{gathered}
\% \text { Recovery }(\mathrm{N} \text { and } \mathrm{OM})= \\
{[(\{\mathrm{kg} \text { of ash } / \mathrm{kg} \text { of DM before }\}} \\
\div\{\mathrm{kg} \text { of ash } / \mathrm{kg} \text { of DM after }\}) \\
\times(\{\mathrm{kg} \text { of } \mathrm{N} \text { or } \mathrm{OM} / \mathrm{kg} \text { of } \mathrm{DM} \text { after }\} \\
\div\{\mathrm{kg} \text { of } \mathrm{N} \text { or } \mathrm{OM} / \mathrm{kg} \text { of } \mathrm{DM} \text { before }\})] \times 100
\end{gathered}
$$

Manure $\mathrm{N}$ was calculated by multiplying manure $\mathrm{N}$ concentration ( $\mathrm{kg}$ of $\mathrm{N} / \mathrm{kg}$ of $\mathrm{DM}$ ) by kilograms of manure removed (DM basis) from the pen surface. Soil core $\mathrm{N}$ was used to correct manure $\mathrm{N}$ for manure left in the pen or soil removed at cleaning. Runoff $\mathrm{N}$ was the $\mathrm{N}$ concentration of the runoff multiplied by the volume of water collected. Manure C:N ratios were calculated using the manure ash concentration (DM basis) to determine the manure $\mathrm{C}$ concentration (DM basis). The formula $\mathrm{C}=(100-\%$ ash $) / 1.8$ was used to estimate C (NRCS, 1992). Percent manure $\mathrm{C}$ was then divided by percent manure $\mathrm{N}$.

Nitrogen excretion was determined by the difference between $\mathrm{N}$ intake and $\mathrm{N}$ retention. Nitrogen intake was calculated using the analyzed dietary $\mathrm{N}$ concentration multiplied by DMI and corrected for $\mathrm{N}$ content of feed refusals. Retention of $\mathrm{N}$ was estimated from actual steer gains, and the NRC (1996) retained energy and retained protein equations. Nitrogen excreted was calculated by subtracting $\mathrm{N}$ retention from $\mathrm{N}$ intake. Total 
$\mathrm{N}$ lost was calculated by subtracting manure $\mathrm{N}$ (corrected for soil $\mathrm{N}$ content) and runoff $\mathrm{N}$ from excreted $\mathrm{N}$. Percentage $\mathrm{N}$ loss was calculated as $\mathrm{N}$ lost divided by total $\mathrm{N}$ excretion. All $\mathrm{N}$ values are expressed on a kilograms per steer basis. Mass balances for OM were calculated using equations similar to those for $\mathrm{N}$, except $\mathrm{OM}$ digestion data were used to calculate $\mathrm{OM}$ excreted.

\section{Sample Analyses}

Once collected, all samples were frozen at $-4^{\circ} \mathrm{C}$ until analysis. To minimize $\mathrm{N}$ losses during the drying process, fecal and manure samples were dried via lyophilization using a Virtis Freezemobile model 25 SL (Virtis, Gardiner, NY). Feeds, feed refusals, and soil cores were oven-dried for $48 \mathrm{~h}$ at $60^{\circ} \mathrm{C}$. Once dried, all samples were ground through a Wiley Mill (1-mm screen). For laboratory analysis, feed refusal, fecal, and manure samples were each composited by weight on a pen basis. Feed samples were collected weekly and composited by month. Soil cores were separated into initial and final samples and composited by pen. Runoff samples were composited by pond using a weighted average of liquid volume. For all composites, total $\mathrm{N}$ was analyzed by the combustion method using a $\mathrm{N}$ analyzer (Leco FP428; Leco Corporation, St. Joseph, MI). All sample composites were analyzed for $\mathrm{OM}$ by ashing at $600^{\circ} \mathrm{C}$ for $6 \mathrm{~h}$ (AOAC, 1996).

\section{Diet Digestibility Calculations}

Fecal $\mathrm{N}$ and $\mathrm{OM}$ excretion by steers were calculated from the DMI and dietary indigestibility measured in previous digestion trials. Digestibility values for diets containing 0\% WCGF were based upon the results of Bierman et al. (1999), who reported an all-concentrate and $7.5 \%$ roughage diet to have DM digestibilities of 83.5 and $80.5 \%$, respectively. A dry-matter digestibility of $82 \%$ was used for the $3.75 \% \mathrm{AH}$ and $0 \%$ WCGF diet, assuming an average between 83.5 and $80.5 \%$. Therefore, DM digestibility values of $83.5,82.0$, and $80.5 \%$ were applied to diets containing 0\% WCGF and 0, 3.75, and $7.5 \% \mathrm{AH}$, respectively. Digestibility values of the diets containing 35\% WCGF were based upon several trials in which corn bran and steep replaced corn in finishing diets. Corn bran and steep are components of WCGF, and diets containing 35\% WCGF contained approximately $24.5 \%$ corn bran (DM basis). Based on previous work (McCoy et al., 1997; Bierman et al., 1999; Erickson and Klopfenstein, 2001b), diets containing $24.5 \%$ corn bran exhibit reduced DM digestibility of $4.8 \%$ compared with a corn-based control diet. This reduction was applied to all diets containing 35\% WCGF. Therefore, DM digestibility values of 78.7, 77.2, and $75.7 \%$ were applied to diets containing $35 \% \mathrm{WCGF}$ and $0,3.75$, and $7.5 \% \mathrm{AH}$, respectively.

The data were analyzed as a completely randomized design using the Mixed procedure of SAS (SAS Inst. Inc., Cary, NC). Pen served as the experimental unit.
The model included AH level, WCGF level, and the interactions among $\mathrm{AH}$ and WCGF level. An AH $\times$ WCGF interaction was only observed for efficiency of gain; thus main effects of AH and WCGF are discussed for all performance and nutrient balance data except efficiency of gain. Linear and quadratic effects of $\mathrm{AH}$ were tested using orthogonal contrasts. Statistics on nutrient runoff were only conducted on main effects of either AH level or WCGF level due to lack of replication for the simple effects.

\section{RESULTS AND DISCUSSION}

\section{Feedlot Performance}

Individual treatment means for effects of diet on steer performance and carcass characteristics are presented in Table 2. Interactions between AH level and WCGF inclusion were not observed $(P \geq 0.50)$ for most steer performance responses, except for efficiency of gain, LM area, and 12th-rib fat depth. Thus, main effects of $\mathrm{AH}$ level and WCGF inclusion are presented for most performance responses, whereas simple effects are discussed for efficiency of gain, LM area, and fat depth. Average daily gain increased $(P=0.03)$ and HCW increased $(P=0.04)$ linearly as AH level increased in the diet. Feeding increasing amounts of $\mathrm{AH}$ also linearly increased $(P=0.01)$ daily DMI. Steers responded similarly to additions of 3.75 and $7.5 \% \mathrm{AH}$ for DMI, $\mathrm{ADG}$, and HCW; however, both levels increased (linear, not quadratic response) DMI, $\mathrm{ADG}$, and $\mathrm{HCW}$ compared with $0 \% \mathrm{AH}$ inclusion. Marbling score was not affected by dietary AH level. Level of AH had no effect on the number of liver abscesses.

Replacing dry-rolled corn with 35\% WCGF increased DMI by $4.7 \%(P<0.01)$, ADG by $3.4 \%(P=0.10)$, and HCW by $1.6 \%(P=0.09)$ compared with no WCGF inclusion. Loin muscle area and 12th-rib fat thickness were also greater $(P \leq 0.01)$ for steers fed 35\% WCGF than those fed no WCGF as a result of greater ADG and $\mathrm{HCW}$. There was a tendency $(P=0.10)$ for an interaction between AH and WCGF for LM area and 12th rib fat thickness. The interaction was primarily caused by steers fed 0\% AH and 0\% WCGF having lower ADG and, therefore, lower LM area and less fat cover.

Efficiency of gain was similar $(P>0.15)$ across $\mathrm{AH}$ inclusion levels when 0\% WCGF was fed; however, efficiency of gain improved linearly $(P=0.06)$ as $\mathrm{AH}$ was removed in diets containing 35\% WCGF. Steers fed 35\% $\mathrm{WCGF}$ and $0 \% \mathrm{AH}$ had greater $(P=0.06) \mathrm{G}: \mathrm{F}$ than steers fed $35 \% \mathrm{WCGF}$ and $7.5 \% \mathrm{AH}$. This observation suggests $\mathrm{AH}$ additions to diets containing 35\% WCGF reduced dietary energy, at least in terms of the efficiency of gain. However, there was a linear increase in $\mathrm{DMI}$ to maintain $\mathrm{ADG}$, suggesting that $\mathrm{AH}$ had less value in controlling acidosis in diets containing $35 \%$ WCGF. Efficiency of steers fed 35\% WCGF and 0\% AH were improved $4.4 \%(P=0.10)$ compared with efficiencies of steers fed $0 \% \mathrm{WCGF}$ and $0 \% \mathrm{AH}$. 
Table 2. Growth performance and carcass characteristics of steers fed dry-rolled corn diets containing combinations of alfalfa hay (AH) and wet corn gluten feed (WCGF; \% of DM)

\begin{tabular}{|c|c|c|c|c|c|c|c|c|c|c|}
\hline \multirow[b]{2}{*}{ Item } & \multicolumn{3}{|c|}{$0 \%$ WCGF } & \multicolumn{3}{|c|}{$35 \% \mathrm{WCGF}$} & \multirow[b]{2}{*}{ SEM } & \multirow[b]{2}{*}{$\mathrm{AH}^{*} \mathrm{WCGF}^{1}$} & \multirow{2}{*}{$\begin{array}{c}\text { Linear } \\
\mathrm{AH}^{2}\end{array}$} & \multirow[b]{2}{*}{$\mathrm{WCGF}^{3}$} \\
\hline & 0 & 3.75 & 7.5 & 0 & 3.75 & 7.5 & & & & \\
\hline No. head (pens) & $32(4)$ & $32(4)$ & $32(4)$ & $32(4)$ & $32(4)$ & 32 & - & - & - & - \\
\hline Initial wt, kg & 351 & 351 & 351 & 352 & 351 & 351 & 0.8 & 0.86 & 0.35 & 0.57 \\
\hline Final wt, ${ }^{4} \mathrm{~kg}$ & 571 & 591 & 591 & 588 & 595 & 596 & 6 & 0.52 & 0.04 & 0.09 \\
\hline$G: F^{5}$ & 0.161 & 0.168 & 0.166 & 0.168 & 0.164 & 0.160 & 0.003 & 0.09 & 0.53 & 0.73 \\
\hline $\mathrm{HCW}, \mathrm{kg}$ & 360 & 372 & 372 & 371 & 375 & 375 & 4 & 0.52 & 0.04 & 0.09 \\
\hline Marbling score ${ }^{6}$ & 499 & 502 & 504 & 494 & 491 & 500 & 12 & 0.94 & 0.63 & 0.50 \\
\hline LM area, ${ }^{7} \mathrm{~cm}^{2}$ & 84.9 & 89.8 & 88.7 & 90.9 & 96.3 & 88.8 & 1.5 & 0.10 & 0.57 & $<0.01$ \\
\hline 12 th rib fat depth, cm & 1.14 & 1.31 & 1.25 & 1.34 & 1.29 & 1.46 & 0.06 & 0.10 & 0.05 & 0.01 \\
\hline Liver abscesses, steers & $2 / 32$ & $2 / 32$ & $0 / 32$ & $1 / 32$ & $1 / 32$ & $1 / 32$ & & & & \\
\hline
\end{tabular}

${ }^{1} P$-value for the interaction between $\mathrm{AH}$ and WCGF.

${ }^{2} P$-value for a linear effect of the AH main effect.

${ }^{3} P$-value for the WCGF main effect.

${ }^{4}$ Calculated as $\mathrm{HCW} \div 63 \%$ (common dressing percent).

${ }^{5} \mathrm{ADG}: \mathrm{DMI}$.

${ }^{6} 450=$ Slight $^{50}, 500=$ Small $^{0}, 550=$ Small $^{50}$, etc.

${ }^{7}$ Quadratic effect of the AH main effect $(P<0.05)$.

Typically, finishing diets are formulated to include a small amount of roughage to minimize digestive disturbances (i.e., ruminal acidosis). Dilution of concentrate (starch) intake is one mechanism in which roughages may reduce digestive disturbances. Galyean and Gleghorn (2001) surveyed nutritionists in the major cattle feeding areas of the United States and reported an average roughage inclusion of $8.9 \%$ diet DM (range 4.5 to $13.5 \%$ diet $\mathrm{DM}$ ). Cattle may be finished on all-concentrate diets; however, adding low levels of roughage increases DMI and ADG (Stock et al., 1990; Huffman et al., 1992; Shain et al., 1999). Huffman et al. (1992) observed a $17 \%$ increase in DMI and a $14 \%$ increase in $\mathrm{ADG}$ with $7.5 \%$ forage addition to feedlot diets compared with an all-concentrate diet. Stock et al. (1990) observed a quadratic increase in DMI and ADG with increasing roughage level from 0 to $9 \% \operatorname{diet} \mathrm{DM}$. They found that 9\% roughage produced maximal intake, whereas $6 \%$ roughage produced maximal gains. Our results would agree with the observation of greater DMI and ADG with a small amount of roughage inclusion into grain-based finishing diets.

Roughage addition to concentrate diets has also shown mixed results on efficiency of gain. Efficiency of gain has been shown to improve (Woods et al., 1969; Brandt et al., 1987; Stock et al., 1990), not change (Huffman et al., 1992; Shain et al., 1996), or be reduced (Stock et al., 1987; Huffman et al., 1992; Van Schaack et al., 1993) with roughage addition to finishing diets. However, the benefit from roughage addition to finishing diets may depend on grain type, grain processing, or both. Stock et al. (1990) reported a decrease in efficiency of gain when roughage was added to diets containing dry-rolled corn or dry-rolled grain sorghum but not to diets containing dry-rolled wheat. Our results suggest only a tendency $(P=0.15)$ for low AH inclusion in dry-rolled corn-based diets to improve efficiency of gain; cattle fed $3.75 \% \mathrm{AH}$ and $0 \% \mathrm{WCGF}$ were $4 \%$ more efficient than those fed the all-concentrate diet $(0 \% \mathrm{AH}$, $0 \%$ WCGF). When roughage levels are evaluated, a combination of both efficiency of gain and ADG need to be evaluated.

The addition of WCGF has produced variable changes in efficiency of gain when fed to cattle consuming high concentrate diets. The factors that may affect the observed efficiency responses include the inclusion level of WCGF (Hussein and Berger, 1995; Sindt et al., 2002) and composition (bran:steep liquor ratio) of the WCGF produced by different wet milling plants (Stock et al., 2000). Richards et al. (1998) observed improved feed efficiencies when WCGF replaced up to $50 \%$ of dryrolled corn. Sindt et al. (2002) observed improved efficiencies when WCGF was fed at $30 \%$ but reduced feed efficiencies when WCGF was fed at $60 \%$. Hussein and Berger (1995) observed a similar quadratic response in gain efficiency with WCGF addition to finishing diets. However, Ham et al. (1995) reported no change in efficiency of gain when WCGF was fed at up to $87.5 \%$ diet DM.

The beneficial response to WCGF in finishing diets is likely a reduction in ruminal acidosis. Likely, the response to WCGF is greater in diets or feeding situations where acidosis is a greater challenge. Presumably, high levels (i.e., $>50 \%$ diet DM) of WCGF reduce dietary energy to an extent that overrides the beneficial effects of highly digestible fiber addition to finishing diets. Krehbiel et al. (1995) and Sindt et al. (2002) observed a reduction in ruminal VFA concentration and an increase in ruminal $\mathrm{pH}$ as WCGF replaced corn grain, indicative of reduced acidosis insult with WCGF inclu- 
sion. Few studies have evaluated reducing roughage levels in finishing diets containing WCGF. Sindt et al. (2001) fed steam-flaked corn-based diets with 3 levels of WCGF $(25,35$, or $45 \%$ DM-basis) and 2 levels of AH ( 2 or $6 \%$ diet $\mathrm{DM}$ ). They reported that reducing $\mathrm{AH}$ level had no effect on intake, gain, or efficiency of gain across WCGF levels and concluded that AH could be reduced to at least $2 \%$ (DM-basis) for SFC-based diets containing at least $25 \%$ WCGF.

The energy value of WCGF was calculated based upon steer performance and dietary ingredient composition (NRC, 1996; Owens et al., 2002). Similar to efficiency of gain, increasing $\mathrm{AH}$ level decreased the dietary $\mathrm{NE}_{\mathrm{g}}$ value with $35 \%$ WCGF inclusion $(1.45,1.35$ and $1.30 \mathrm{Mcal} / \mathrm{kg}$ for diets containing $0,3.75$, and $7.5 \%$ $\mathrm{AH}$, respectively). These data suggest that reducing or completely removing AH improves efficiency of gain and maintains ADG of feedlot steers fed dry-rolled cornbased diets containing 35\% WCGF. Presumably, greater levels of WCGF (i.e., $35 \%$ diet DM) are needed to provide equivalent benefit as $\mathrm{AH}$ inclusion (i.e., 3.75 or $7.5 \%$ diet $\mathrm{DM})$. Although the WCGF used in the current study contained similar NDF as the AH (approximately $50 \%$ of DM for both WCGF and AH), the effective NDF is much greater in AH than WCGF (92 vs. 36\% NDF; NRC, 1996); therefore, greater levels of WCGF may be needed to substitute AH in finishing cattle diets. Grain-processing methods that increase ruminal starch digestibility (i.e., high-moisture or steam-flaked corn) may influence the optimum amount of roughage to include in finishing diets containing WCGF. Presumably, more intensely processed corn may require additional or different combinations of roughage or WCGF for optimal performance compared with dry-rolled corn diets. Few data are available evaluating different corn processing methods in diets containing WCGF and interactions with roughage level.

\section{Nitrogen Balance}

Interactions between AH and WCGF were not observed for feedlot $\mathrm{N}$ mass balance; therefore, only main effects of AH and WCGF are presented. As level of $\mathrm{AH}$ increased in diets, $\mathrm{N}$ intake, $\mathrm{N}$ retention and $\mathrm{N}$ excretion increased linearly $(P<0.05$; Table 3$)$. Greater $\mathrm{N}$ intake and retention were a result of greater DMI and ADG with increasing levels of $\mathrm{AH}$. Based upon modeled growth, $\mathrm{N}$ retention was approximately $15 \%$ of $\mathrm{N}$ intake across all levels of $\mathrm{AH}$. The percentage $\mathrm{N}$ in manure increased with increasing levels of $\mathrm{AH}(P=$ 0.09 ). Total $\mathrm{N}$ in manure was numerically increased by the same proportion but was not statistically different between dietary levels of $\mathrm{AH}$ due to variation in manure removal amounts. The amount of as-is (wet weight) and DM manure removed from the pen surface was similar among AH levels (Table 4). However, the percentage $\mathrm{OM}$ in manure increased linearly $(P<0.06)$ with increasing dietary $\mathrm{AH}$ level, and as a result more OM was removed from the pen surface when cattle were
Table 3. Effect of alfalfa hay (AH) level on $\mathrm{N}$ mass balance (except where noted, values are expressed as kilograms per steer over the entire feeding period)

\begin{tabular}{|c|c|c|c|c|c|}
\hline Item & $\begin{array}{l}0 \% \\
\mathrm{AH}\end{array}$ & $\begin{array}{c}3.75 \% \\
\mathrm{AH}\end{array}$ & $\begin{array}{c}7.5 \% \\
\mathrm{AH}\end{array}$ & SEM & Linear $^{1}$ \\
\hline $\mathrm{N}$ intake & 29.8 & 31.4 & 31.9 & 0.3 & $<0.01$ \\
\hline $\mathrm{N}$ retention ${ }^{2}$ & 4.3 & 4.6 & 4.6 & 0.08 & $<0.05$ \\
\hline $\mathrm{N}$ excretion ${ }^{3}$ & 25.4 & 26.8 & 27.3 & 0.3 & $<0.01$ \\
\hline Fecal N & 6.2 & 7.2 & 8.1 & 0.16 & $<0.01$ \\
\hline Manure N & 3.65 & 4.36 & 4.41 & 0.47 & 0.27 \\
\hline Soil N & -0.18 & 0.11 & 0.82 & 0.64 & 0.28 \\
\hline Manure + soil $\mathrm{N}^{4}$ & 3.47 & 4.47 & 5.23 & 0.85 & 0.16 \\
\hline Runoff $\mathrm{N}$ & 1.18 & 0.96 & 1.11 & 0.10 & 0.65 \\
\hline $\mathrm{N} \mathrm{lost} \mathrm{t}^{5}$ & 20.8 & 21.4 & 21.0 & 0.8 & 0.88 \\
\hline $\mathrm{N}$ loss, ${ }^{6} \%$ & 81.9 & 79.8 & 76.6 & 3.0 & 0.23 \\
\hline$\% \mathrm{~N}$ manure & 1.13 & 1.23 & 1.30 & 0.07 & 0.09 \\
\hline
\end{tabular}

${ }^{1} P$-value for the linear effect of $\mathrm{AH}$ level.

${ }^{2}$ Calculated using NRC (1996) net protein and net energy equations.

${ }^{3}$ Calculated as $\mathrm{N}$ intake $-\mathrm{N}$ retention.

${ }^{4}$ Corrected for soil $\mathrm{N}$ concentration before and after trial.

${ }^{5}$ Calculated as $\mathrm{N}$ excretion - (manure $\mathrm{N}+$ runoff $\left.\mathrm{N}\right)$.

${ }^{6}$ Calculated as $\mathrm{N}$ lost $\div \mathrm{N}$ excretion.

fed AH $(P<0.10)$ compared with the all-concentrate diet. As a result of more $\mathrm{OM}$ removal with $\mathrm{AH}$ inclusion, the C:N ratio of manure increased linearly $(P=0.05)$ with increasing $\mathrm{AH}$.

Steers fed WCGF had greater N intake $(P<0.01$; Table 5) than those fed no WCGF, as a result of slightly greater dietary $\mathrm{N}$ concentration and greater DMI. Dietary $\mathrm{N}$ concentration was greater in WCGF containing diets due to slight underestimation of CP in the WCGF product before the beginning of the experiment. Crude protein was estimated because WCGF was delivered to the feedlot 2 to 3 times weekly throughout the experiment. Due to greater ADG and final weights, steers fed WCGF had greater $\mathrm{N}$ retention $(P=0.10)$ based on modeled growth; however, the increase in $\mathrm{N}$ retention did not compensate for the increase in $\mathrm{N}$ intake, resulting in a $9 \%$ increase in $\mathrm{N}(P<0.01)$ excretion when cattle were fed WCGF. Nitrogen retention was 14.9 and $14.3 \%$ of $\mathrm{N}$ intake in the 0 and 35\% WCGF fed steers, respectively. Kilograms of $\mathrm{N}$ lost from the pen surface were greater when pens housed steers fed WCGF $(P=$

Table 4. Effect of alfalfa hay (AH) level on manure removed from the pen surface (values are expressed as kilograms per steer over the entire feeding period)

\begin{tabular}{lccccc}
\hline \hline Item & $0 \%$ & $3.75 \%$ & $7.5 \%$ & & \\
\hline As-is removal, kg & 470 & 530 & 494 & 79 & 0.84 \\
\% DM & 70.9 & 70.0 & 70.8 & 0.62 & 0.91 \\
DM removal, kg & 334 & 369 & 350 & 56 & 0.83 \\
\% OM & 20.2 & 23.2 & 24.9 & 1.6 & 0.06 \\
OM removal, kg & 65 & 81 & 83 & 7 & 0.10 \\
Manure C:N ratio $^{2}$ & 9.9 & 10.4 & 10.5 & 0.2 & 0.05 \\
\hline
\end{tabular}

${ }^{1} P$-value for the linear effect of alfalfa hay level.

${ }^{2}$ Carbon to nitrogen ratio of manure removed at cleaning, in which $\mathrm{C}=(100-\%$ ash $) / 1.8$. 
Table 5. Effect of 0 or $35 \%$ wet corn gluten feed (WCGF) inclusion on $\mathrm{N}$ mass balance (except where noted, values are expressed as kilograms per steer over the entire feeding period)

\begin{tabular}{|c|c|c|c|c|}
\hline Item & $\begin{array}{c}0 \% \\
\text { WCGF }\end{array}$ & $\begin{array}{l}3.75 \% \\
\text { WCGF }\end{array}$ & SEM & $P$-value \\
\hline $\mathrm{N}$ intake & 29.9 & 32.2 & 0.3 & $<0.01$ \\
\hline $\mathrm{N}$ retention ${ }^{1}$ & 4.4 & 4.6 & 0.06 & 0.10 \\
\hline $\mathrm{N}$ excretion ${ }^{2}$ & 25.4 & 27.6 & 0.2 & $<0.01$ \\
\hline Fecal N & 6.1 & 8.2 & 0.13 & $<0.01$ \\
\hline Manure N & 3.37 & 4.90 & 0.39 & 0.01 \\
\hline Soil N & 0.526 & -0.025 & 0.522 & 0.46 \\
\hline Manure + soil $\mathrm{N}^{3}$ & 3.90 & 4.88 & 0.69 & 0.33 \\
\hline Runoff $\mathrm{N}$ & 1.34 & 0.78 & 0.08 & $<0.01$ \\
\hline $\mathrm{N}$ lost ${ }^{4}$ & 20.2 & 21.9 & 0.7 & 0.08 \\
\hline $\mathrm{N} \operatorname{loss},{ }^{5} \%$ & 79.2 & 79.6 & 2.5 & 0.92 \\
\hline$\% \mathrm{~N}$ manure & 1.17 & 1.28 & 0.06 & 0.17 \\
\hline
\end{tabular}

${ }^{1}$ Calculated using NRC (1996) net protein and net energy equations. ${ }^{2}$ Calculated as $\mathrm{N}$ intake $-\mathrm{N}$ retention.

${ }^{3}$ Corrected for soil $\mathrm{N}$ concentration before and after trial.

${ }^{4}$ Calculated as $\mathrm{N}$ excretion - (manure $\mathrm{N}+$ runoff $\mathrm{N}$ ).

${ }^{5}$ Calculated as $\mathrm{N}$ lost $\div \mathrm{N}$ excretion.

0.08); however, because WCGF fed steers excreted more $\mathrm{N}$, there was no difference in the percentage $\mathrm{N}$ loss from pens. When expressed as a percentage of $\mathrm{N}$ excretion, losses of $\mathrm{N}$ from pens where steers were fed 0 and $35 \%$ WCGF were not different, averaging 79.2 and $79.6 \%$, respectively.

The percentage $\mathrm{N}$ in manure was 1.17 and $1.28 \%$ $(P=0.17)$ for 0 and $35 \%$ WCGF fed steers, respectively. However, manure N (unadjusted for soil N) was $45 \%$ greater $(P=0.01)$ when cattle were fed WCGF. This is likely a result of greater OM excretion, because amount of $\mathrm{N}$ in manure is directly correlated to $\mathrm{OM}$ in manure (Bierman et al., 1999; Erickson and Klopfenstein, 2001a). When manure $\mathrm{N}$ was adjusted for soil $\mathrm{N}$ before and after the trial, treatments were not different due to variation in samples. However, the trend for greater manure $\mathrm{N}$ when steers were fed WCGF was still evident (3.9 vs. $4.9 \mathrm{~kg} / \mathrm{steer}$ for 0 and 35\% WCGF diets, respectively).

Feeding 35\% WCGF resulted in a $40 \%$ increase in manure removal at the end of the feeding period $(P=$ 0.08 ) compared with pens in which cattle were fed no WCGF (Table 6). The percentage moisture was greater in manure removed from pens housing steers fed WCGF, and more manure DM tended $(P=0.11)$ to be removed from these pens. Similar to AH, feeding WCGF resulted in a greater percentage $\mathrm{OM}$ in manure $(P=$ 0.07 ) and more total OM removed from the pen surface at pen cleaning $(P<0.01)$. The greater $\mathrm{OM}$ in manure from steers fed 35\% WCGF translated into an elevated manure $\mathrm{C}: \mathrm{N}$ ratio $(P=0.02)$ as compared with steers fed no WCGF.

Bierman et al. (1999) reported a linear relationship between $\mathrm{N}$ and $\mathrm{OM}$ in manure. They fed an all-concentrate diet to minimize fecal output and compared it to a diet containing $7.5 \%$ roughage to increase fecal output
Table 6. Effect of 0 or $35 \%$ wet corn gluten feed (WCGF) inclusion on manure (pen scrapings) removed from the pen surface (values expressed as kilograms per steer over the entire feeding period)

\begin{tabular}{lcccr}
\hline \hline & $0 \%$ & $3.75 \%$ & & \\
Item & WCGF & WCGF & SEM & $P$-value \\
\hline As-is removal, kg & 414 & 581 & 64 & 0.08 \\
\% DM & 71.7 & 69.5 & 0.5 & 0.01 \\
DM removal, kg & 297 & 405 & 46 & 0.11 \\
\% OM & 20.9 & 24.6 & 1.3 & 0.07 \\
OM removal, kg & 60 & 92 & 6 & $<0.01$ \\
Manure C:N ratio $^{1}$ & 9.9 & 10.6 & 0.2 & 0.02 \\
\hline
\end{tabular}

${ }^{1}$ Carbon to nitrogen ratio of manure removed at cleaning, in which $\mathrm{C}=(100-\%$ ash $) / 1.8$.

and a diet with $41.5 \%$ WCGF to further increase fecal output. Pens housing steers fed $41.5 \%$ WCGF resulted in greater $\mathrm{OM}$ and $\mathrm{N}$ removal in manure at pen cleaning compared with an all concentrate or $7.5 \%$ roughage diet. Erickson and Klopfenstein (2001a) also reported a linear relationship between $\mathrm{OM}$ in manure and $\mathrm{N}$ retention in manure. Similar to Bierman et al. (1999), low level of roughage addition (i.e., 7.5\% $\mathrm{AH}$ ) did not influence manure $\mathrm{N}$ as much as $35 \%$ WCGF inclusion. This was likely a result of lower fecal output by steers fed AH compared with those fed WCGF.

If manure $\mathrm{N}$ is increased, volatilization of $\mathrm{N}$ into the atmosphere can be reduced. One method to retain $\mathrm{N}$ in manure is increasing the OM content or C:N ratio of manure. Direct (i.e., sawdust, straw bedding, and other high OM sources) and indirect (reducing diet digestibility) methods of OM application have been evaluated. Carbon additions have been observed to reduce $\mathrm{N}$ losses from cattle manure (Dewes, 1996) and pig slurry (Andersson, 1996; Subair et al., 1999). Erickson and Klopfenstein (2001b) fed diets to reduce diet digestibility, thereby increasing $\mathrm{OM}$ excretion to the pen surface. Nitrogen volatilization was reduced by 15 and $21 \%$ in open feedlots when 15 and $30 \%$ corn bran replaced corn in finishing diets, respectively. However, the reduction in $\mathrm{N}$ volatilization by reducing dietary digestibility was only achieved during the fall and spring feeding months. Identical dietary treatments had no effect on $\mathrm{N}$ losses when steers were fed during the warmer summer months. Adams et al. (2004) compared N losses by adding $\mathrm{OM}$ via 2 separate methods. Sawdust was applied to pens or corn bran was fed ( $30 \%$ diet DM) to increase $\mathrm{OM}$ on the pen surface. Losses of $\mathrm{N}$ were evaluated in 2 separate trials during separate times of the year. Feeding corn bran and applying sawdust reduced $\mathrm{N}$ losses by 41 and $46 \%$, respectively, compared with a corn-based diet when steers were fed from November to May; however, similar to Erickson and Klopfenstein (2001b), N losses were not influenced when additional OM was applied to pens housing steers fed from May to September. Bierman et al. (1999) observed an increase in manure $\mathrm{N}$ by feeding $41.5 \%$ WCGF (reduced $\mathrm{DM}$ digestibility). However, $\mathrm{N}$ volatilization from pen 
surfaces was greater than that of an all-concentrate diet as a result of WCGF fed steers consuming and excreting more N. Furthermore, steers were fed during the summer months when OM addition to the pen surface has limitations at reducing $\mathrm{N}$ losses from the feedlot pen surface. Our results agree with Bierman et al. (1999). Manure N was increased by increasing OM excretion and the $\mathrm{C}: \mathrm{N}$ ratio of manure. However, this increase in manure $\mathrm{N}$ did not relate to a reduction in volatilization losses, likely because of the time of year steers were fed or $\mathrm{N}$ intake. Presumably, not enough $\mathrm{OM}$ was added to the pen surface or $\mathrm{N}$ volatilized before it could be immobilized by microbial activity due to warm summer temperatures. Moreover, steers fed WCGF excreted more $\mathrm{N}$ as a result of greater $\mathrm{N}$ intake, resulting in more $\mathrm{N}$ available for volatilization.

Evaluating the mass balance approach to $\mathrm{N}$ losses in open feedlots, Klopfenstein and Erickson (2002) reported that $\mathrm{N}$ volatilization losses are approximately 20 to $30 \%$ greater during the summer months than those of the winter/spring (November to May) feeding months. Duysen et al. (2003) observed a positive correlation between $\mathrm{NH}_{3}$ flux and surface or soil temperature on a beef feedlot using a wind tunnel placed on the pen surface. The authors observed $\mathrm{NH}_{3}$ flux to be the greatest during August $\left(10.4 \mu \mathrm{g}^{*} \mathrm{~m}^{-2 *} \mathrm{~s}^{-1}\right)$ and lowest during February $\left(1.2 \mu \mathrm{g}^{*} \mathrm{~m}^{-2} *_{\mathrm{s}}{ }^{-1}\right)$. Hutchinson et al. (1982) also observed greater $\mathrm{NH}_{3}$ flux during warmer sampling periods (July) as compared with cooler sampling periods (April). Our data indicate that losses of $\mathrm{N}$ from open feedlots are high during the summer months. Approximately $80 \%$ of $\mathrm{N}$ excretion was volatilized from the pen surface, regardless of dietary treatment. Although previous research has demonstrated the ability of additional $\mathrm{OM}$ on the pen surface to reduce $\mathrm{N}$ losses, this method may only be beneficial during cooler times of the year. Additional OM from feeding WCGF may not reduce $\mathrm{N}$ loss during the summer feeding months, but testing during the winter/spring months is warranted. Regardless of time of year, feeding WCGF will most likely increase the amount of manure needing to be removed from pens.

Nitrogen in runoff was greater from pens where cattle were fed no WCGF $(P<0.01)$ as compared with those pens fed 35\% WCGF with pond replicated across main effect of WCGF treatment. However, expressed as a percentage of $\mathrm{N}$ excretion, $\mathrm{N}$ in runoff was relatively low for both dietary treatments, averaging approximately 5 and 3\% for 0 and 35\% WCGF pens, respectively. This observation agrees with Bierman et al. (1999), who observed greater $\mathrm{N}$ in runoff from pens housing cattle consuming an all-concentrate diet. Furthermore, these data affirm that regardless of diet, $\mathrm{N}$ in runoff is not a large contributor to $\mathrm{N}$ losses from open feedlots and agrees with previous findings (Gilbertson et al., 1971; Erickson and Klopfenstein, 2001a; Adams et al., 2004).

\section{Organic Matter Balance}

Organic matter intake increased linearly with increasing AH inclusion into diets $(P<0.01$; Table 7$)$, and
Table 7. Effect of alfalfa hay (AH) level on OM balance (except for \% loss, values expressed as kilograms per steer over the entire feeding period; DM basis)

\begin{tabular}{|c|c|c|c|c|c|}
\hline Item & $\begin{array}{l}0 \% \\
\mathrm{AH}\end{array}$ & $\begin{array}{c}3.75 \% \\
\mathrm{AH}\end{array}$ & $\begin{array}{c}7.5 \% \\
\mathrm{AH}\end{array}$ & SEM & Linear \\
\hline OM intake & 1,302 & 1,377 & 1,401 & 14 & $<0.01$ \\
\hline $\mathrm{OM}_{\text {excretion }}{ }^{2}$ & 208 & 255 & 280 & 5 & $<0.01$ \\
\hline Manure OM & 65 & 81 & 83 & 7 & $<0.10$ \\
\hline Soil OM ${ }^{3}$ & -3.3 & 4.5 & 0.7 & 13.5 & 0.83 \\
\hline Manure + soil $\mathrm{OM}^{4}$ & 61.4 & 85.6 & 83.6 & 16.2 & 0.34 \\
\hline Runoff $\mathrm{OM}^{5}$ & 5.6 & 10.1 & 8.0 & 0.3 & 0.01 \\
\hline OM lost ${ }^{6}$ & 141 & 159 & 189 & 15 & 0.03 \\
\hline OM loss, ${ }^{7} \%$ & 68.8 & 62.9 & 66.8 & 6.2 & 0.82 \\
\hline
\end{tabular}

${ }^{1} P$-value for linear effect of alfalfa hay level.

${ }^{2}$ Calculated as DMI $\times(\mathrm{DM}$ indigestibility of the $\operatorname{diet} \times \mathrm{OM}$ concentration in feces).

${ }^{3}$ Soil OM balance based on cores collected before and after trial.

${ }^{4}$ Manure OM corrected for soil OM concentration before and after trial.

${ }^{5}$ Quadratic $(P<0.05)$.

${ }^{6}$ Calculated as OM excretion - (manure OM [corrected for soil] + runoff $\mathrm{OM}$ ).

${ }^{7}$ Calculated as OM lost $\div$ OM excretion.

when WCGF was fed $(P<0.01$; Table 8$)$. This was a result of greater DMI when steers were fed $\mathrm{AH}$ or WCGF. Based upon DMI and indigestibility of diets, $\mathrm{OM}$ excretion was calculated. Organic matter excretion followed a similar trend as OM intake and increased linearly $(P<0.01)$ with increasing dietary $\mathrm{AH}$ levels. Steers fed 35\% WCGF excreted approximately $34 \%$ more $(P<0.01)$ OM than those fed no WCGF. Greater $\mathrm{OM}$ excretion was a result of replacing part of the dietary corn with less digestible ingredients $(\mathrm{AH}$ or WCGF). Bierman et al. (1999) also observed an increase OM excretion when cattle were fed $7.5 \%$ roughage or 41.5\% WCGF compared with cattle fed an all-concentrate diet. More OM (kg/steer) ended up in runoff when

Table 8. Effect of 0 or $35 \%$ wet corn gluten feed (WCGF) inclusion on OM balance (except for \% loss, values expressed as kilograms per steer over the entire feeding period; DM basis)

\begin{tabular}{lcccr}
\hline \hline & $0 \%$ & $3.75 \%$ & & \\
Item & WCGF & WCGF & SEM & $P$-value \\
\hline OM intake & 1,328 & 1,392 & 12 & $<0.01$ \\
OM excretion $^{1}$ & 212 & 283 & 4 & $<0.01$ \\
Manure OM & 60 & 92 & 6 & $<0.01$ \\
Soil OM $^{2}$ & 6 & -5 & 11 & 0.48 \\
Manure + soil OM $^{3}$ & 66 & 87 & 13 & 0.27 \\
Runoff OM $_{\text {OM lost }}^{4}$ & 6.7 & 9.1 & 0.2 & $<0.01$ \\
OM loss, $^{5} \%$ & 139 & 187 & 12 & 0.01 \\
\hline
\end{tabular}

${ }^{1}$ Calculated as DMI $\times(\mathrm{DM}$ indigestibility of the diet $\times \mathrm{OM}$ concentration in feces).

${ }^{2}$ Soil OM balance based on cores collected before and after trial.

${ }^{3}$ Manure OM corrected for soil OM concentration before and after trial.

${ }^{4}$ Calculated as OM excretion - (manure OM [corrected for soil] + runoff $\mathrm{OM})$.

${ }^{5}$ Calculated as OM lost $\div$ OM excretion. 
cattle were fed $35 \%$ WCGF compared with no WCGF $(P<0.01)$, mimicking OM excretion. However, OM runoff, as a percent of OM excretion was similar for 0 and $35 \%$ WCGF diets (3.2\% of OM excretion). The runoff percentages are in agreement with others (Gilbertson et al., 1971; Erickson and Klopfenstein, 2001a), indicating little OM leaves the pen surface in liquid runoff.

The amount of OM removed in manure increased linearly for increasing levels of AH $(P<0.10)$. Inclusion of both 3.75 and $7.5 \% \mathrm{AH}$ resulted in $26 \%$ more OM removal in manure at pen cleaning. Inclusion of $35 \%$ WCGF into diets resulted in $53 \%$ more $(P<0.01) \mathrm{OM}$ removal in manure when compared with no WCGF inclusion. This was a result of greater OM intake and reduced dietary digestibility with $\mathrm{AH}$ or WCGF inclusion into diets and agrees with Erickson and Klopfenstein (2001a). Bierman et al. (1999) also reported an increase in the amount of OM removed in manure when similar levels of AH or WCGF were included into diets compared with an all concentrate diet. Likewise, Erickson and Klopfenstein (2001a,b) and Adams et al. (2004) reported greater OM removal in manure by reducing diet digestibility (corn bran inclusion).

Amount of OM lost from pen surfaces followed a trend similar to OM excretion. More OM was lost (kg/steer) from pens when steers were fed 35\% WCGF $(P=0.01)$ and with increasing levels of $\mathrm{AH}(P=0.03)$. Organic matter loss averaged approximately $66 \%$ across $\mathrm{AH}$ levels and with either level of WCGF inclusion. Organic matter is more volatile during the warm summer months as compared with winter-spring feeding months (Erickson and Klopfenstein, 2001a; Adams et al., 2004). Our results agree with Erickson and Klopfenstein (2001a), who reported upwards of $62 \%$ OM loss during the summer feeding months. However, Bierman et al. (1999) reported lower volatilization of OM with similar diets fed to steers during similar times of the year. The authors reported 27, 9, and 7\% OM volatilization losses with diets containing $41.5 \%$ WCGF, $7.5 \%$ roughage, or an all-concentrate diet.

\section{Compost Nutrient Recovery}

Manure from pens assigned to the same dietary treatments was composted in 1 windrow (4 pens/compost windrow; 6 compost windrows total). Nutrient recoveries are based upon manure removed at pen cleaning and finished compost samples. Manure $\mathrm{N}$ was $45 \%$ greater and compost $\mathrm{N}$ was $66 \%$ greater when steers were fed $35 \%$ WCGF compared with $0 \%$ WCGF inclusion. Percentage $\mathrm{N}$ recovery was 39.7 and $45.4 \%$ for 0 and $35 \%$ WCGF diets, respectively. Percentage $\mathrm{N}$ recovery was 41 to $45 \%$ for compost from cattle fed different AH levels. These data agree with Adams et al. (2004) who observed greater $\mathrm{N}$ recovery in finished compost when steers were fed corn bran to increase OM excretion. Presumably, greater $\mathrm{N}$ recovery in compost with WCGF or AH inclusion into diets, or both, was a result of greater OM excretion. Organic matter followed a trend similar to $\mathrm{N}$ and was greater in manure and in finished compost when steers were fed 35\% WCGF compared with $0 \%$ WCGF. Percentage OM recovery was $47.6 \%$ for 0 and $35 \%$ WCGF inclusion; however, manure OM was greater in initial manure with steers fed $35 \%$ WCGF compared with no WCGF inclusion, resulting in 55\% more OM in finished compost with $35 \%$ WCGF inclusion into diets. Addition of $\mathrm{AH}$ to diets also increased OM in manure and subsequently in compost but not to the extent of feeding WCGF. Average recovery of OM was $47.6 \%$ for AH treatments as well.

\section{IMPLICATIONS}

Incorporation of wet corn gluten feed or alfalfa hay into finishing diets increases intake and gain. Results indicate that $35 \%$ wet corn gluten feed inclusion into feedlot diets containing dry-rolled corn allows for less roughage to be fed. Additions of alfalfa hay to dry-rolled corn-based diets containing wet corn gluten feed may reduce efficiency of gain and the apparent energy value of diets. The fibrous characteristics of wet corn gluten feed may replace the roughage requirement in finishing diets, albeit greater amounts of wet corn gluten feed than roughage seem needed. Addition of $35 \%$ wet corn gluten feed increased manure nitrogen removal and nitrogen in finished compost, likely as a result of greater organic matter on the pen surface. Nitrogen losses from pen surfaces are high during the summer feeding months, and additional organic matter excretion may not reduce losses during these times of the year.

\section{LITERATURE CITED}

Adams, J. R., T. B. Farran, G. E. Erickson, T. J. Klopfenstein, C. N. Macken, and C. B. Wilson. 2004. Effect of organic matter addition to the pen surface and pen cleaning frequency on nitrogen balance in open feedlots. J. Anim. Sci. 82:2153-2163.

Andersson, M. 1996. Performance of bedding materials in affecting ammonia emissions from pig manure. J. Agric. Eng. Res. 65:213-222.

AOAC. 1996. Official Methods of Analysis. 13th ed. Assoc. Off. Anal. Chem., Washington, DC.

Bierman, S., G. E. Erickson, T. J. Klopfenstein, R. A. Stock, and D. H. Shain. 1999. Evaluation of nitrogen and organic matter balance in the feedlot as affected by level and source of dietary fiber. J. Anim. Sci. 77:1645-1653.

Brandt, R. T., S. J. Anderson, and J. K. Elliot. 1987. Forage levels in steam-flaked wheat finishing diets. Pages 18-21 in SW Kansas Branch Agric. Exp. Sta. Rep. Prog. 518. Manhattan, KS.

Clark, R. N., A. D. Schneider, and B. A. Stewart. 1975. Analysis of runoff from southern great plains feedlots. Trans. ASAE 18:319-322.

Dewes, T. 1996. Effect of $\mathrm{pH}$, temperature, amount of litter and storage density on ammonia emissions from stable manure. J. Agric. Sci. (Camb.) 127:501-509.

Duysen, R., G. Erickson, D. Schulte, and R. Stowell. 2003. Ammonia, hydrogen sulfide and odor emissions from a beef cattle feedlot. ASAE Annu. Int. Meet. Paper No. 034109.

Erickson, G. E., and T. J. Klopfenstein. 2001a. Managing N inputs and the effect on $\mathrm{N}$ losses following excretion in open-dirt feedlots in Nebraska. In Optimizing Nitrogen Manage. Food Energy Prod. Environ. Prot.: Proc. 2nd Int. Nitrogen Conf. Sci. Policy. Sci. World 1(S2), 830-835. 
Erickson, G. E., and T. J. Klopfenstein. 2001b. Nutritional methods to decrease $\mathrm{N}$ losses from open-dirt feedlots in Nebraska. In Optimizing Nitrogen Manage. Food Energy Prod. Environ. Prot.: Proc. 2nd Int. Nitrogen Conf. Sci. Policy. Sci. World 1(S2), 836-843.

Galyean, M. L., and J. F. Gleghorn. 2001. Summary of the 2000 Texas Tech University consulting nutritionist survey. Burnett Center Internet Progress Report. No. 12. Available: http://www.afs. ttu.edu/burnett_center/progress_reports/Accessed June 3, 2003.

Gilbertson, C. B., T. M. McCalla, J. R. Ellis, O. E. Cross, and W. R. Woods. 1971. Runoff, solid wastes, and nitrate movement in beef feedlots. J. Water Pollut. Control Fed. 43:483-493.

Ham, G. A., R. A. Stock, T. J. Klopfenstein, and R. P. Huffman. 1995. Determining the net energy value of wet and dry corn gluten feed in beef growing and finishing diets. J. Anim. Sci. 73:353-359.

Huffman, R. P., R. A. Stock, M. H. Sindt, and D. H. Shain. 1992. Effect of fat type and forage level on performance of finishing cattle. J. Anim. Sci. 79:3889-3898.

Hussein, H. S., and L. L. Berger. 1995. Effects of feed intake and dietary level of wet corn gluten feed on feedlot performance, digestibility of nutrients, and carcass characteristics of growingfinishing beef heifers. J. Anim. Sci. 73:3246-3252.

Hutchinson, G. L., A. R. Mosier, and C. E. Andre. 1982. Ammonia and amine emissions from a large cattle feedlot. J. Environ. Qual. 11:288-293.

Klopfenstein, T. J., and G. E. Erickson. 2002. Effects of manipulating protein and phosphorus nutrition of feedlot cattle on nutrient management and the environment. J. Anim. Sci. 80(E. Suppl. 2):E106-E114.

Krehbiel, C. R., R. A. Stock, D. W. Herold, D. H. Shain, G. A. Ham, and J. A. Carulla. 1995. Feeding wet corn gluten feed to reduce acidosis in cattle. J. Anim. Sci. 73:2931-2939.

McCoy, R., C. Richards, T. Scott, R. Stock, T. Klopfenstein, and D. Herold. 1997. Digestibility of dry-rolled corn, wet corn gluten feed, and alfalfa hay in receiving and finishing diets. Neb. Beef Cattle Rep. MP 67-A:61-64.

National Research Council. 1996. Nutrient Requirements of Beef Cattle. 7th rev. ed. Natl. Acad. Sci., Washington, DC.

National Resources Conservation Service. 1992. Part 651, Chap. 4, Page 6 in Agricultural Waste Management Field Handbook. Agricultural Waste Characteristics. Available: http://www. wcc.nrcs.usda.gov/awm/awmfh.html Accessed Jan. 15, 2003.
Owens, F. N., M. A. Hinds, and D. W. Rice. 2002. Methods for calculating diet energy values from feedlot performance of cattle. J. Anim. Sci. 80(Suppl. 1):273.

Richards, C. J., R. A. Stock, T. J. Klopfenstein, and D. H. Shain. 1998. Effect of wet corn gluten feed, supplemental protein, and tallow on steer finishing performance. J. Anim. Sci. 76:421-428.

Shain, D. H., R. A. Stock, T. J. Klopfenstein, and D. W. Herold. 1999. The effect of forage source and particle size on finishing yearling steer performance and ruminal metabolism. J. Anim. Sci. 77:1082-1092.

Shain, D., R. Stock, T. Klopfenstein, and M. Klemersud. 1996. Roughage source and particle size in finishing diets. Neb. Beef Cattle Rep. MP 66-A:56-57.

Sindt, J. J., J. S. Drouillard, J. N. Pike, S. P. Montgomery, C. M. Coetzer, T. B. Farran, T. J. Kessen, and R. T. Ethington. 2001. Alfalfa hay and wet corn gluten feed levels in steam-flaked corn finishing diets. KAES Rep. Progr. No. 873:98.

Sindt, J. J., J. S. Drouillard, H. Thippareddi, R. K. Phebus, D. L. Lambert, S. P. Montgomery, T. B. Farran, H. J. LaBrune, J. J. Higgins, and R. T. Ethington. 2002. Evaluation of finishing performance, carcass characteristics, acid-resistant $E$. coli and total coliforms from steers fed combinations of wet corn gluten feed and steam-flaked corn. J. Anim. Sci. 80:3328-3335.

Stock, R. A., D. R. Brink, K. K. Kreikemeier, and K. K. Smith. 1987. Evaluation of early-harvested and reconstituted grain sorghum in finishing steers. J. Anim. Sci. 65:548-556.

Stock, R. A., J. M. Lewis, T. J. Klopfenstein, and C. T. Milton. 2000. Review of new information on the use of wet and dry milling feed by-products in feedlot diets. Proc. Am. Soc. Anim. Sci. 1999. Available at: http://www.asas.org/jas/symposia/proceedings/ 0924.pdf Accessed Oct. 1, 2003.

Stock, R. A., M. H. Sindt, J. C. Parrott, and F. K. Goedeken. 1990. Effects of grain type, roughage level and monensin level on finishing cattle performance. J. Anim. Sci. 68:3441-3455.

Subair, S., J. W. Fyles, and I. P. O’Halloran. 1999. Ammonia volatilization from liquid hog manure amended with paper products in the laboratory. J. Environ. Qual. 28:202-207.

Van Schaack, P., T. L. Stanton, D. Schutz, and P. Grover. 1993. Effects of alfalfa level with whole shelled corn on feedlot steer performance and carcass characteristics. Pages 61-66 in Beef Prog. Rep. Colorado State Univ., Fort Collins.

Woods, W., W. Tolman, and D. Clanton. 1969. Forage levels in finishing rations. Neb. Beef Cattle Rep. EC 69-218:14. 